\title{
Correction: Intracranial haemangiopericytoma: a rare case presenting with haemorrhage
}

Abdelsadg M, Kanodia AK, Smith C, et al. Intracranial haemangiopericytoma: a rare case presenting with haemorrhage. BMJ Case Rep 2018; doi:10.1136/bcr-2018-224351.

The correct full name of the fifth author is Khaled Badran.

(C) BMJ Publishing Group Ltd (unless otherwise stated in the text of the article) 2018. All rights reserved. No commercial use is permitted unless otherwise expressly granted.

BMJ Case Rep 2018. doi:10.1136/bcr-2018-224351corr1

A Check for updates

Copyright 2018 BMJ Publishing Group. All rights reserved. For permission to reuse any of this content visit http://group.bmj.com/group/rights-licensing/permissions.

BMJ Case Report Fellows may re-use this article for personal use and teaching without any further permission.

Become a Fellow of BMJ Case Reports today and you can:

- Submit as many cases as you like

- Enjoy fast sympathetic peer review and rapid publication of accepted articles

- Access all the published articles

- Re-use any of the published material for personal use and teaching without further permission

For information on Institutional Fellowships contact consortiasales@bmjgroup.com

Visit casereports.bmj.com for more articles like this and to become a Fellow 